UDC 639.371.52 (477)

(C) 2017

I. Grytsyniak, Academician of the NAAS, Doctor of Agricultural Sciences V. Gurbik, N. Mykhailenko Institute of Fisheries of NAAS

\title{
FISH FARMING AND BIOLOGICAL CHARACTERISTICS OF AGE-2 GALICIAN CARP IN CONDITIONS OF INDUSTRIAL GROWING IN PONDS OF
}

The purpose. To study productive characteristics of age-2 Galician carp in conditions of industrial growing. Methods. Standard procedures in fish farming and selection. Results. Data are gained on productive features of age-2 Galician carp at various densities of fishes during industrial growing in ponds of Prikarpattia. It is revealed that irrespective of density of fishes Galician carp has high temp of body height. Economic assessment of age- 2 Galician carp by exterior parameters is given. Conclusions. Galician carp at growing age-2 fishes in industrial conditions of ponds of Prikarpattia has high economic parameters both on individual mass of fishes, and on the general productivity.

Key words: temp of body height, exterior, Galician carp, specific growth rate.

Introduction (problem statement). In recent years, there has been a tendency for increasing the species composition of cultivated fish species. Particular attention is needed for rearing fish, which are in high demand due to their gastronomic properties and fast growth rates. After all, these criteria are fundamental when determining the competitiveness and quality of fish products.

Highly important is also the restoration of valuable indigenous minor carp groups in Ukraine, to which, unfortunately, the Galician carp belong. Therefore, the study and analysis of the productive characteristics of this group under the conditions of modern industrial cultivation is of special urgency.

The Galician carp deserves attention, because it is the most ancient form grown in Ukraine. At present, specimens of this group have remained only in several farms of the Lviv region. Consequently, for industrial reproduction and 
assessment of the Galician carp as an object of industrial cultivation, it is necessary to study its productive characteristics on different stages of the technological process.

\section{Analysis of last achievements and publications devoted to the studied}

topic. The development of pond aquaculture on the ethnic lands of Ukraine with the construction of special ponds for fish keeping and rearing in the western regions began in the XIV century. The formation of fish farming and fishing in Galicia is considered to be started at the end of the XVIII and the first half of the XIX century. During this period, in order to popularize the fishery industry in Europe, a number of exhibitions for experience exchange were held [1,2].

The Galician carp was first presented during the agricultural exhibition in Berlin in 1880 by the Kaniov farm, which was located on the territory of Galicia. The presented carp had good flesh properties and a relatively fast growth rate [3,4].

Over the past few years, the prevailing interest in pond fish farming in inland water bodies of Ukraine remains unchanged. The dominating role in domestic pond aquaculture is played by enterprises, which specialize in carp culture [5].

The growth of aquaculture products is possible only with an overall intensification. One of the most important ways of intensification is the improvement of the productive qualities of the cultured objects, which is achieved by creating new high-productive fish breeds or by restoring native ones [6].

\section{Study objects and methods.}

Growing age-2 Galician carp was carried out at the fish farm "Korop" of the Lviv region in 2015-2016 based on semi-intensive technology in monoculture conditions. The total area of the growing pond of the II order was 2.5 ha.

The pond was stocked with age-1 fish obtained after wintering, the mean weight of which in 2015 was 110 g, in 2016 - 96 g. For the assessment of productive properties of the Galician carp, different stocking densities were used. E.g., growing of fish seeds in 2015 and 2016 was done with different stocking densities: 1.0 thousand fish/ha and 2.3 thousand fish/ha, respectively. 
During the growing season, the ecological condition of fish keeping was studied by monitoring the hydrochemical parameters of the growing pond and the development of the natural food supply. The development of the natural food supply of the experimental pond was studied according to generally accepted hydrobiological methods [7-9].

During the growing season, fish were additionally fed by grain, where the daily ration was calculated according to methodical recommendations [10].

The main economic-biological parameters of age-2 Galician carp were studied during control catches, spring inventory and autumn catches according to the generally accepted methods of aquaculture. Exterior features were used for assessing the economic characteristics of the Galician carp [10].

The growth rate of the Galician carp as one of the main parameters of productivity was assessed by determining the weight gain in absolute and relative values.

The weight accumulation rate is one of the major parameters of fish productivity because fast growing fish provide a higher productivity gain per unit of time. Age-2 Galician carp growth was characterized based on weight gains during the growing season and the specific growth rate of I. I. Shmalgauzen [12, 13].

\section{Study results.}

Hydrochemical analysis of experimental pond water showed that it was moderately mineralized and belonged to the hydrocarbonate class (Table 1).

Table 1

Dynamics of water quality parameters of the experimental pond at the fish

\begin{tabular}{|l|c|c|c|r|}
\multicolumn{5}{l}{ farm "Korop" in 2016} \\
\hline Water quality parameter & 17.05 & 15.07 & 1.11 & $\begin{array}{r}\text { Normal } \\
\text { range for } \\
\text { pond water }\end{array}$ \\
\hline $\mathrm{pH}$ & 8.3 & 7.3 & 7.4 & $6.5-8.5$ \\
\hline Free ammonium, $\mathrm{NH}_{3 .}, \mathrm{mgN} / \mathrm{dm}^{3}$ & 0.03 & 0.01 & 0.03 & up to 0.05 \\
\hline Permanganate value, $\mathrm{mgO} / \mathrm{dm}^{3}$ & 10.9 & 14.5 & 13.4 & up to 15.0 \\
\hline
\end{tabular}




\begin{tabular}{|l|c|c|c|r|}
\hline dichromate value, $\mathrm{mgO} / \mathrm{dm}^{3}$ & 27.3 & 36.2 & 33.4 & up to 50.0 \\
\hline Ammonium nitrogen, $\mathrm{NH}_{4}, \mathrm{mgN} / \mathrm{dm}^{3}$ & 0.62 & 1.27 & 6.7 & up to 1.0 \\
\hline Nitrites, $\mathrm{NO}_{2}, \mathrm{mgN} / \mathrm{dm}^{3}$ & 0.06 & 0.11 & 0.19 & up to 0.1 \\
\hline Nitrates, $\mathrm{NO}_{3}, \mathrm{mgN} / \mathrm{dm}^{3}$ & 0.08 & 0.15 & 0.47 & up to 2.0 \\
\hline Mineral phosphorus, $\mathrm{PO}_{4}, \mathrm{mgP} / \mathrm{dm}^{3}$ & 0.12 & 0.33 & 0.87 & up to 0.5 \\
\hline Total iron, $\mathrm{Fe}^{2+}+\mathrm{Fe}^{3+}, \mathrm{mgFe} / \mathrm{dm}^{3}$ & 0.44 & 1.56 & 1.89 & up to 1,0 \\
\hline Calcium, $\mathrm{Ca}^{2+}, \mathrm{mg} / \mathrm{dm}^{3}$ & 52.1 & 78.2 & 88.2 & up to 70 \\
\hline Magnesium, $\mathrm{Mg}^{2+}, \mathrm{mg} / \mathrm{dm}^{3}$ & 8.5 & 3.6 & 2.4 & up to 30 \\
\hline Sodium + potassium, $\mathrm{Na}^{+}+\mathrm{K}^{+} \mathrm{mg} / \mathrm{dm}^{3}$ & 8.3 & 4.8 & 1.5 & up to 50 \\
\hline Hydrocarbonates, $\mathrm{HCO}_{3}, \mathrm{mg} / \mathrm{dm}^{3}$ & 170.9 & 207.5 & 256.3 & up to 400 \\
\hline Chlorides, $\mathrm{Cl}, \mathrm{mg} / \mathrm{dm}^{3}$ & 15.3 & 13.9 & 11.0 & up to 70 \\
\hline Sulfates, $\mathrm{SO}, \mathrm{mg} / \mathrm{dm}^{3}$ & 19.3 & 28.8 & 7.4 & up to 60 \\
\hline Total harness, $\mathrm{mg}-\mathrm{eKB}^{3} / \mathrm{dm}^{3}$ & 3.3 & 4.2 & 4.6 & $5-7$ \\
\hline Mineralization, $\mathrm{mg} / \mathrm{dm}^{3}$ & 274.4 & 336.8 & 366.8 & up to 1000 \\
\hline
\end{tabular}

The dynamics of the development bottom communities in the pond was characterized by peaks and recessions. The highest the development of bottom communities were observed in June and August. During this period, the quantitative development of the macrozoobenthos was within the range of 155 ind. $/ \mathrm{m}^{2}-200$ ind. $/ \mathrm{m}^{2}$ in number and $1.0-1.3$ ind. $/ \mathrm{m}^{2}$ in biomass. The lowest values of food resources were recorded in March, when the biomass was 0.3 ind. $/ \mathrm{m}^{2}$ while the number did not exceed 31 ind. $/ \mathrm{m}^{2}$ (Fig. 1). 


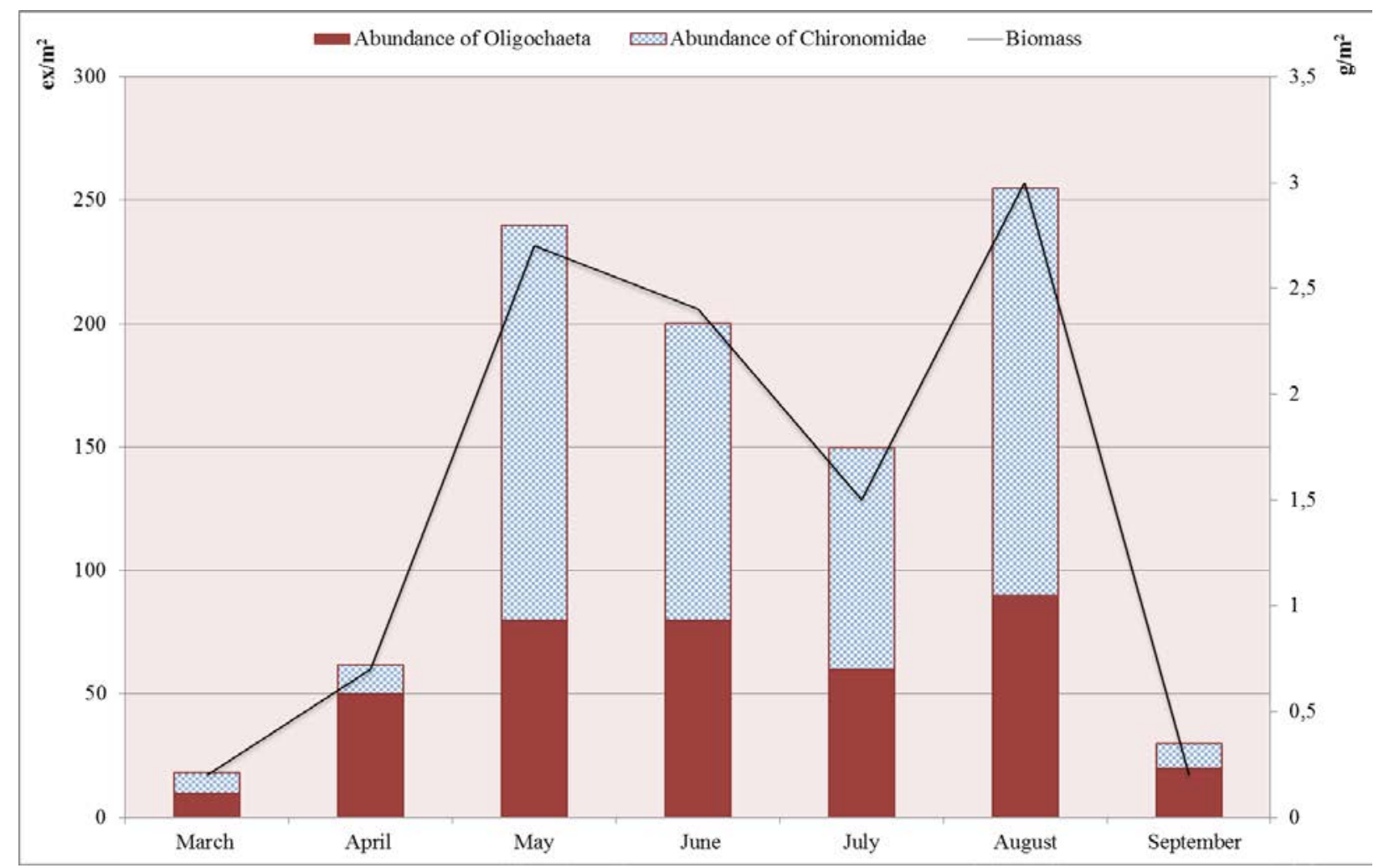

Fig. 1 The dynamics of the development of bottom communities in the experimental ponds of the fish farm "Korop"

During the culture period, the age-2 Galician carp were additionally fed with wheat grain, where the daily ration was calculated according to methodical recommendations [12].

At the end of the culture period, age-2 carp were obtained with mean weight of $1650 \mathrm{~g}$ in 2015 and $1700 \mathrm{~g}$ in 2016 (Table 2).

Table 2

Efficiency of the Galician carp growing with different stocking densities at the fish farm "Korop"

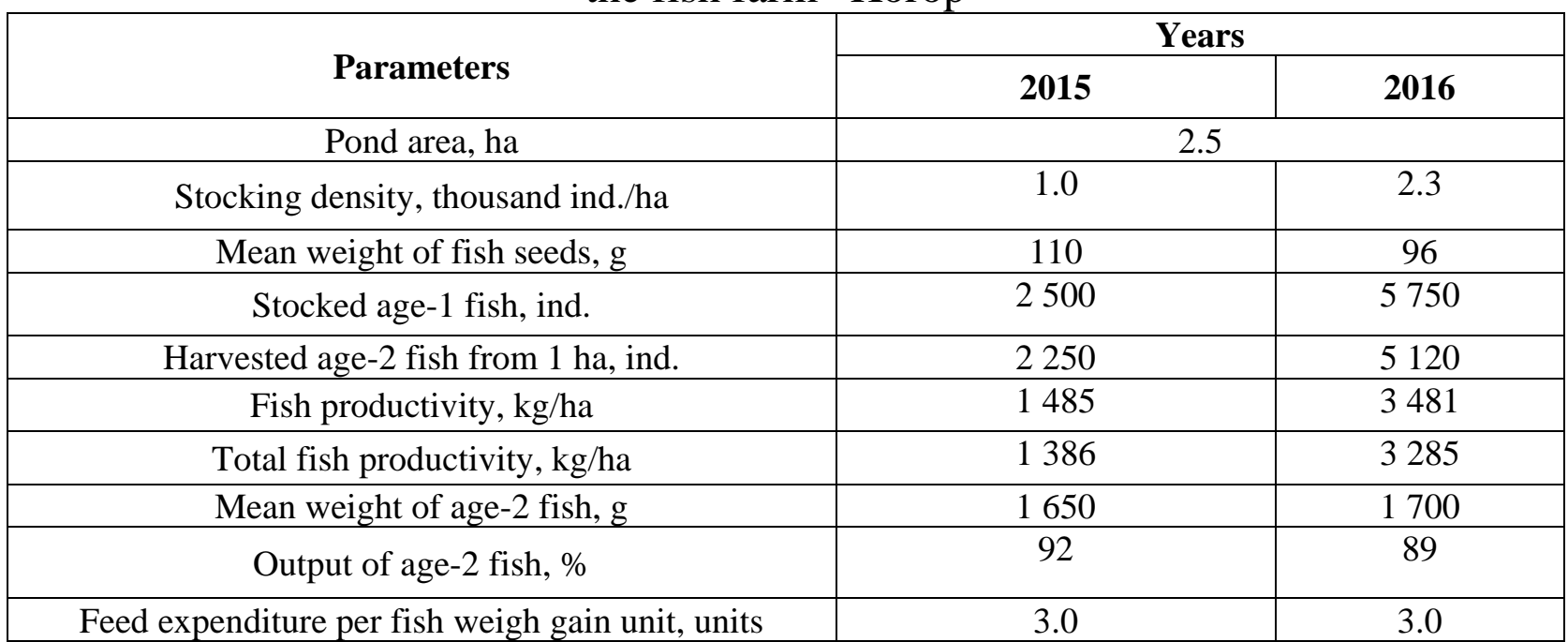


The output of the Galician carp was within $89-92 \%$. Total fish productivity in 2016 exceeded that of 2015 by $1899 \mathrm{~kg} / \mathrm{ha}$.

During fish growing, control fish harvests were performed, the results of which are presented on the Fig. 2.

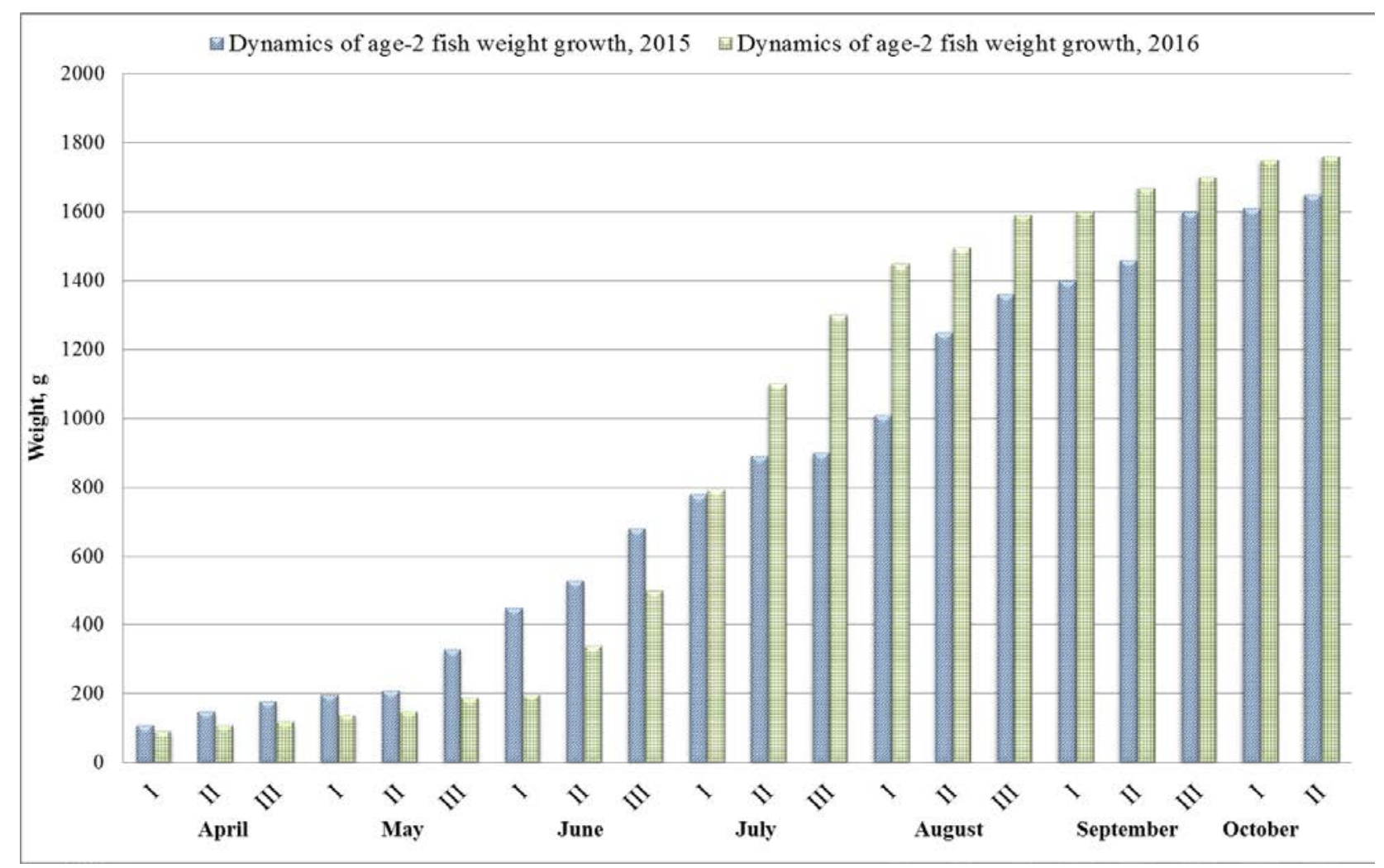

Fig. 2 Weight growth of the Galician carp seeds at the fish farm "Korop”

An intensive weight gain of fish seeds in 2016 was observed at the beginning of July. Such a trend was due to more intensive metabolism caused by an increase in the thermal regime and better utilization of forage objects of the pond. A decrease in the weight gain during the growing season was observed at the beginning of the growing season.

The highest value of the absolute weight gain in 2016 was observed at the third decade of July that increased the value of 2015 by $200 \mathrm{~g}$. An increase in the relative weight gain in 2016 was $28 \%$ at the second decade of June and about $20 \%$ at the beginning of July. In 2015, the highest level of relative weight gain of 36\% was observed at the beginning of the growing season and further this value did not 
exceed $20 \%$. The lowest weight gain values were observed at the beginning and end of the growing season (Fig. 3).

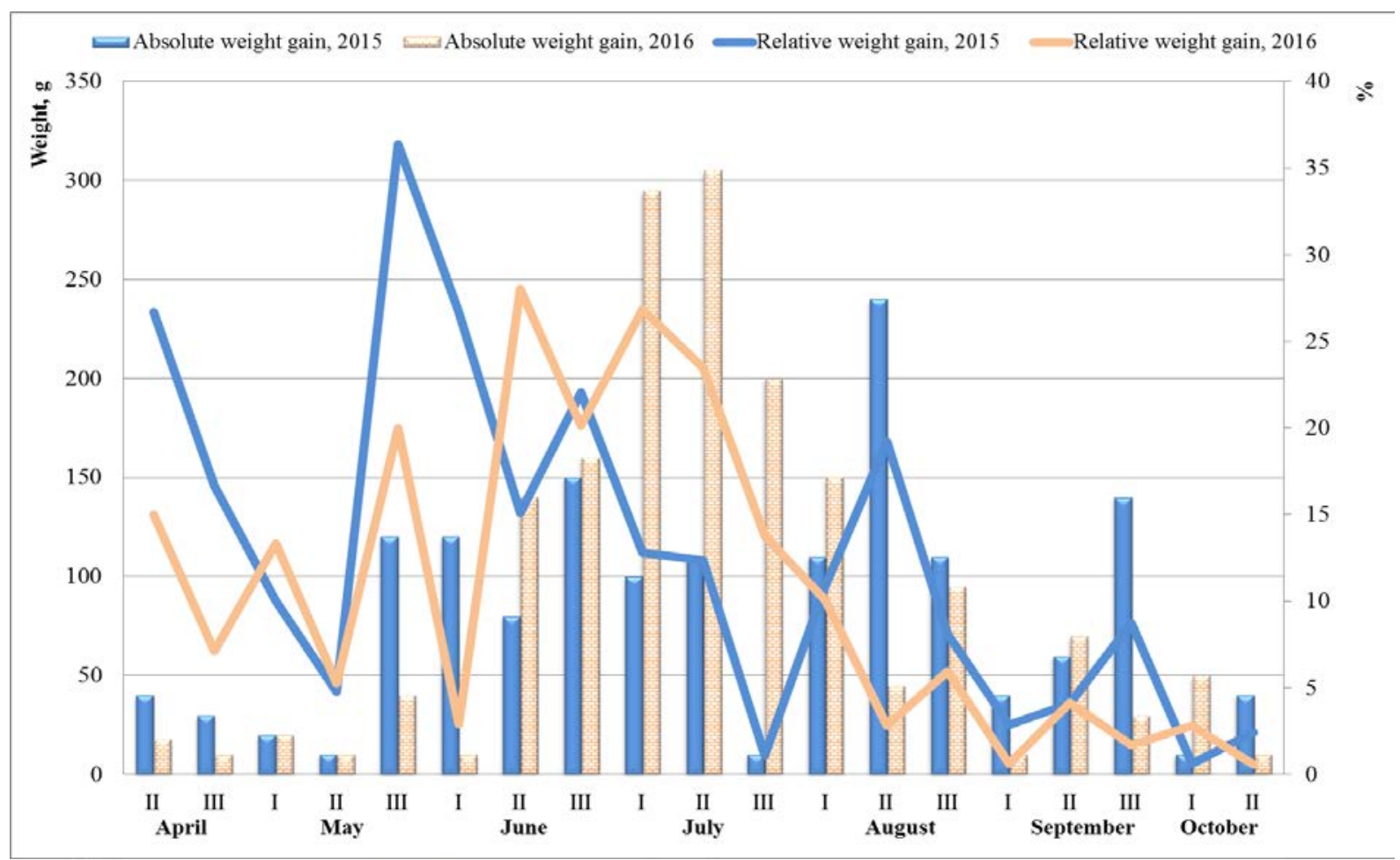

Fig. 3 Absolute weigh gain of age-2 Galician carp in 2015 - 2016

An analysis of growth peculiarities of the Galician carp according to the data of control catches was performed with the aid specific growth rate (Fig. 4).

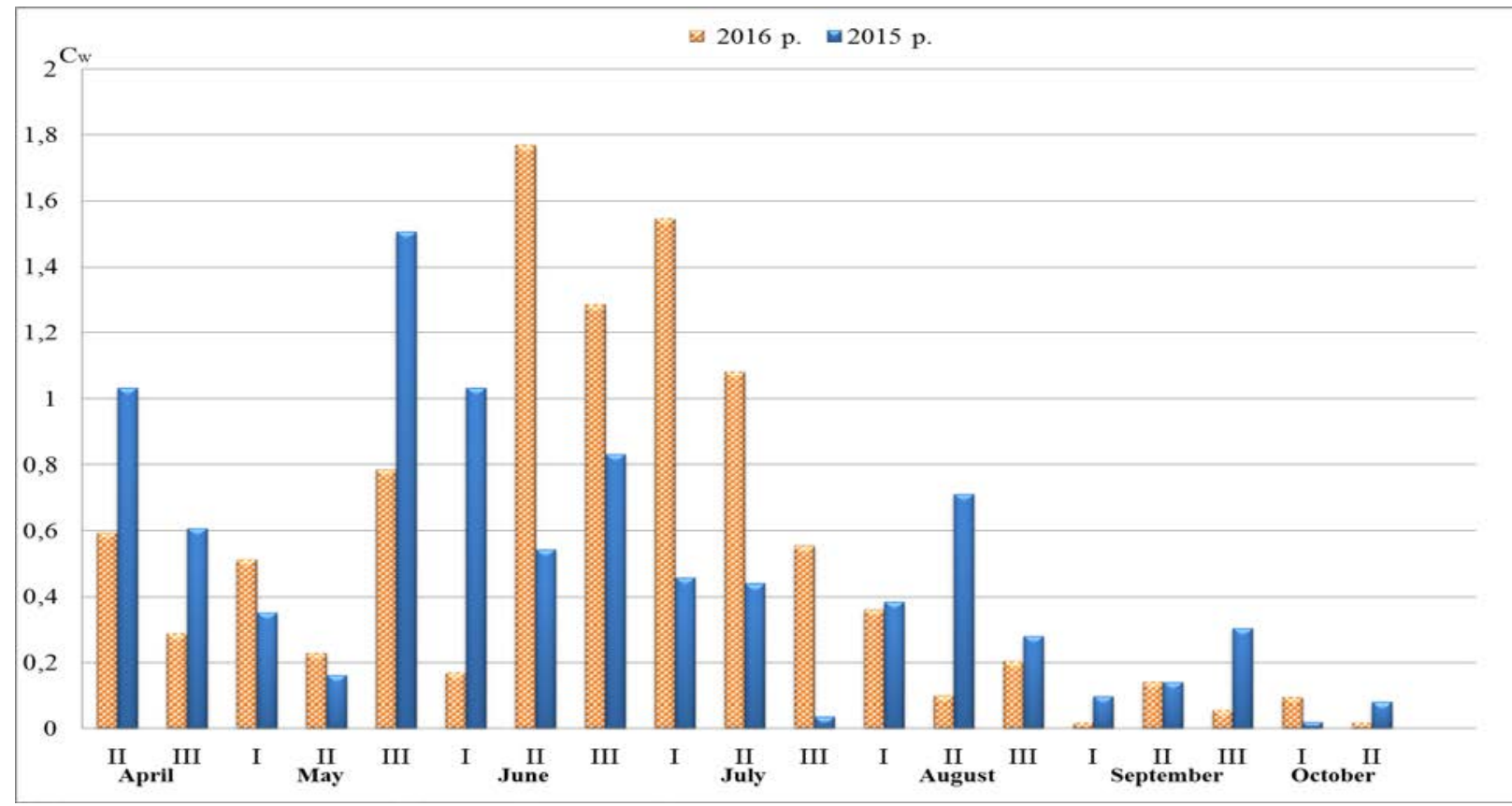

Fig. 4 Dynamics of the specific growth rate of the Galician carp at the fish farm "Korop" during growing seasons in 2015 and 2016 
The Fig. 4 shows that the specific growth rate of age- 2 is characterized by a certain dynamics. The highest weight accumulation value in 2016 was observed at the second half of June, while the peak of growth in 2015 was observed at the third decade of May. The general decline in the growth rate of age-2 Galician carp during the study period was observed at the third decade of August with further decrease. The lowest growth rate during the entire growing period was observed at the first decade of September in 2016 and third decade of July in 2015.

Exterior parameters were used for assessing the fisheries characteristics of the Galician carp. So, at the beginning of the growing season, the condition factor of age-2 Galician carp was at the level of $2.6 \pm 0.3$, during autumn harvest it gradually increased by 30\%. After spring inventory, the relative length of the head was $6.1 \pm 0.5$, at the end of growing this parameter reduced by almost $25 \%$ that indicated on fleshy body structure of age-2 Galician carp. The body length to highest body depth index also has a trend for an increase (Table 3).

Table 3

Exterior parameters of age-2 Galician carp $(n=10), 2016$

\begin{tabular}{|c|c|c|c|c|c|c|c|c|}
\hline \multirow[t]{2}{*}{ Date } & \multicolumn{3}{|c|}{ Weight, $\Gamma$} & \multirow{2}{*}{$\begin{array}{l}\text { conditi } \\
\text { on } \\
\text { factor }\end{array}$} & \multicolumn{4}{|c|}{ Exterior parameters: } \\
\hline & $\max$ & $\min$ & $\underline{M \pm m}$ & & $\mathrm{l} / \mathrm{H}$ & $1 / 0$ & $1 / \mathrm{C}$ & $\mathrm{l}_{\text {udal }}$ \\
\hline 31.03.2016 & 105 & 78,2 & $92 \pm 5.8$ & $2.6 \pm 0.4$ & $3.0 \pm 0.2$ & $1.4 \pm 0.1$ & $6.1 \pm 0.5$ & $2.0 \pm 0.5$ \\
\hline $\mathrm{CV}$ & - & - & 8.4 & 19.2 & 9.7 & 6.9 & 9.4 & 29.6 \\
\hline$\sigma$ & & & 7.8 & 0.5 & 0.3 & 0.1 & 0.6 & 0.6 \\
\hline 15.07.2016 & 910 & 680 & $795 \pm 62.4$ & $3.4 \pm 0.2$ & $2.2 \pm 0.1$ & $1.1 \pm 0.1$ & $3.3 \pm 0.2$ & $1.9 \pm 0.2$ \\
\hline $\mathrm{CV}$ & - & - & 9.3 & 8.5 & 6.4 & 3.1 & 6.6 & 12.8 \\
\hline$\sigma$ & & & 74.2 & 0.3 & 0.1 & 0.1 & 0.2 & 0.2 \\
\hline 15.10.2016 & 2000 & 1500 & $\begin{array}{l}1704 \pm 133 . \\
6\end{array}$ & $4.2 \pm 0.7$ & $2.2 \pm 0.3$ & $1.4 \pm 0.1$ & $4.4 \pm 0.13$ & $1.6 \pm 0.2$ \\
\hline $\mathrm{CV}$ & - & - & 10.1 & 20.2 & 9.2 & 7.8 & 3.7 & 19.8 \\
\hline$\sigma$ & - & - & 171.6 & 0.8 & 0.3 & 0.1 & 0.2 & 0.3 \\
\hline
\end{tabular}

Conclusion. The Galician carp during the period of age-2 fish growing in industrial conditions in ponds of Subcarpathia is characterized by high fisheries parameters such as individual fish weight and general fish productivity. The output of age- 2 fish after the end of the growing season was $89-92 \%$. Thus, the Galician carp is one of high productive objects of carp culture for pond aquaculture. 
For further studies of fisheries-biological parameters of the Galician carp, it is necessary to assess age-3 fish in the conditions of industrial growing in ponds of Subcarpathia.

\section{Bibliography}

1. Międzynarodowa wystawa rybacka w Wiedniu (1903). Okólnik Rybacki, 64, 152 $-163$.

2. Gurbyk, V. V. \& Hrytsynyak I. I. (2016). Istorychni aspekty rybohospodars'koho vykorystannya masyvu halyts'koho koropa (ohlyad). Rybohospodarska nauka Ukrayiny, 3, 77-87.

3. Guziur, J. \& Białowąs, H. \& Milczarzewicz, W. (2003). Ribactwo stawowe w stavach karpiowych, urządzeniach pezemysłowych oraz małych zbiornikach śródlądowych. Warszawa.

4. Białowąs, H. (1998). Linie hodowlane Karpia w Polsce: Linia Polska nr 6 Gołyska. Przegląd Rybacki, 2. 40-42.

5. Ghrycynjak I. I., Ghrynzhevskyj M. V., Tretjak O. M., Kiva M. C., Mruk A. I. (2008). Fermersjke rybnyctvo. Kyiv: Gherb.

6. Oleksijenko O. O (2009). Antoninsjko-zozulenecjkyj typ - strukturna lanka ukrajinsjkykh porid koropa. Tavrijsjkyj naukovyj visnyk, 32, 157-163.

7. Alekin, O. A., Semenov, A. D., \& Skopintsev B. A. (1973). Rukovodstvo po khimicheskomu analizu vod sushi. Lviv: Gidrometeoizdat.

8. Syara Ya. I. (1978). Metodicheskie ukazaniya po gidrokhimicheskim issledovaniyam v prudovykh rybnykh khozyaystvakh. Lvov: Vil'na Ukraïna.

9. Metodicheskie rekomendatsii po sboru i obrabotke materialov pri gidrobiologicheskikh issledovaniyakh na presnovodnykh vodoemakh. Zoobentos $i$ ego produktsiya.(1982). Lviv.

10. Galasun, P. T. (1976). Rybovodno - biologicheskiy kontrol' v prudovykh khozyaystvakh. Moscva: Pishchevaya promyshlennost.

11. Shmalgauzen I. I. (1935). Opredelenie osnovnykh ponyatiy i metodika issledovaniya rosta. Rost zhivotnykh.

12. Zheltov Yu.A. (2006). Organizatsiya kormleniya raznovozrastnogo karpa v fermerskikh rybnykh khozyaystvakh. Kiev:firma «Inkos»

13. Shpet G. I. (1967). Effektivnost ispolzovaniya pishchi na rost u ryb i teplovodnykh zhivotnykh. Rybnoe khozyaystvo, 5, 63-71. 